\title{
Psychological well-being of adolescents gifted in math, humanities and sports: Comparative analysis
}

\author{
E. N. Volkova ${ }^{1}$, S. A. Bezgodova ${ }^{1}$, A. V. Miklyaeva ${ }^{\boxplus 1}$, I. V. Volkova ${ }^{2}$ \\ ${ }^{1}$ Herzen State Pedagogical University of Russia, 48 Moika Emb., Saint Petersburg 191186, Russia \\ ${ }^{2}$ Russian Academy of Education, 8 Pogodinskaya Str., Moscow 119121, Russia
}

\begin{abstract}
Authors
Elena N. Volkova,

SPIN: 6932-2512,

Scopus AuthorID: 35486087600 ,

ResearcherID: G-8595-2015,

ORCID: 0000-0001-9667-4752,

e-mail: e.n.volkova@yndex.ru

Svetlana A. Bezgodova,

SPIN: 6644-6059,

Scopus AuthorID: 57128588500,

ResearcherID: D-5173-2017,

ORCID: 0000-0001-5425-7838,

e-mail: s.a.besgodova@gmail.com

Anastasia V. Miklyaeva,

SPIN: 9471-8985,

Scopus AuthorID: 53984860100,

ResearcherID: D-4700-2017,

ORCID: 0000-0001-8389-2275,

e-mail: a.miklyaeva@gmail.com

Irina V. Volkova,

SPIN: 9742-9840,

ResearcherID: B-6469-2016, ORCID: 0000-0002-3531-7257, e-mail: irina.volkova.mail@gmail.com

\section{For citation:}

Volkova, E. N., Bezgodova, S. A., Miklyaeva, A. V., Volkova, I. V. (2020) Psychological well-being of adolescents gifted in math, humanities and sports: Comparative analysis. Psychology in Education, vol. 2 , no. 4 , pp. 358-365. DOI:10.33910/2686-9527-2020-2-4358-365
\end{abstract}

Received 3 August 2020; reviewed 30 August 2020; accepted 30 August 2020.

Funding: This research was funded by Russian Foundation for Basic Research (RFBR), project No. 19-013-00729.

Copyright: (c) The Authors (2020). Published by Herzen State Pedagogical University of Russia. Open access under CC BY-NC 4.0.
Abstract. Psychological well-being is an important factor for the successful realisation of gifted adolescents' potential, and therefore research in this subject area has not only theoretical, but also practical significance. The results of contemporary research on gifted adolescents' well-being are contradictory, and several decades of discussions about the relationship between giftedness and psychological well-being have yielded no consensus. This ambiguity may arguably be explained by the gifted adolescents' activity type and gender. In this article, a study of the psychological well-being of adolescents $(n=168$, age 15-17) gifted in math, humanities and sports who are enrolled in advanced programmes for gifted children is presented. The eudemonic concept of psychological well-being developed by Carol Ryff served as the theoretical framework of the study. Respondents' psychological well-being was measured using Ryff's Psychological Well-Being Scales as adapted into Russian by L. V. Zhukovskaya and E. G. Troshikhina. The study aimed to identify and analyse possible differences in the psychological well-being of gifted teenagers depending on their gender and type of giftedness. The results suggest that while the respondents' general well-being score is not determined by their type of giftedness or gender, specific factors of psychological well-being, such as purpose in life and self-acceptance, do correlate with giftedness type. The highest scores were found in the sample of adolescents who are gifted in humanities. All detected gender differences fall under age-specific trends of personal development in adolescence, and giftedness type might reinforce these trends. The results of current study contribute to better understanding of the relationship between psychological well-being and giftedness in adolescence.

Keywords: psychological well-being, gifted teenagers, giftedness in math, giftedness in humanities, giftedness in sports. 


\section{Introduction}

Recent psychological studies pay special attention to the psychological well-being of gifted children and teenagers, which is widely considered essential for their self-fulfilment in both professional activities and personal development (Kroesbergen, Van Hooijdonk, Van Viersen et al. 2016; Neihart 1999). According to the World Health Organization, gifted children are a high-risk group for unsatisfactory personal and social development. In this regard, it is important to study the relationship between psychological well-being and giftedness in order to solve emerging tasks in psychological and educational practice.

Psychological well-being is defined as a relevant reflection of one's current personal functioning level and the ability to realise one's fill potential, which is subjectively expressed in satisfaction with oneself and life in general. According to Carol Ryff (Ryff 1989; 2014), there are 6 factors of psychological well-being (purpose in life, autonomy, environmental mastery, personal growth, positive relations with others, and self-acceptance). In self-determination theory, Richard Ryan and Edward Deci emphasize that psychological well-being is determined by the ability to make personal choice and personally improve (Ryan, Deci 2001; Ryan, Huta, Deci 2008). Thus, psychological well-being is not reduced to subjective happiness, reflecting the meaningfulness of one's life and the nature of their attitude towards life.

Although studies of psychological well-being of gifted children are numerous, their results are contradictory. On one hand, a number of studies argue that gifted children tend to have higher estimates of psychological well-being than children who fall within the normal range of ability. These results were confirmed for American, Turkish and Russian samples (Boazman, Sayler 2011; Nail, Evans 1997; Tatli 2017; Rodenko 2010), as well as by the metanalytical study by Timothy Jones (Jones 2013). However, other studies revealed a lower psychological well-being score in gifted children (Fouladchanga, Kohgard, Salah 2010; Vedikova, Kalyagina 2018). There are also a number of studies that found no difference between gifted children's and their regular peers' psychological well-being estimates (Bergold, Wirthwein, Rost, Steinmayr 2015; Zeidner, ShaniZinovich 2011; Jin, Moon 2006).

There are several possible explanations for this inconsistency. First, the definition of giftedness is inconclusive; therefore, researchers could rely on different criteria when labelling respondents as gifted. Based on the analysis of theoretical models of giftedness, Bettina Harder, Wilma Vialle and
Albert Ziegler point to five methods of identifying giftedness (Harder, Vialle, Ziegler 2014). The variety of inclusion criteria makes it difficult to compare study results (Peterson 1997). Second, estimates of psychological well-being of gifted children might be influenced by the variety of giftedness types (Neihart 1999; Martin, Burns, Schonlau 2010). Most of the studies include teenagers with intellectual, or academic, giftedness. However, even this group is not homogenous in their psychological well-being score (Jones 2013). Third, the contradictory results might suggest a connection between psychological well-being and age and gender. Several studies demonstrate that girls tend to have higher estimates of psychological well-being than boys in both gifted and regular groups (Jones 2013; Chen, Fan, Cheung, Wu 2018; Viejo, Gomez-Lopez, Ortega-Ruiz 2018). In the same time, gifted girls may have lower-thanregular scores of psychological well-being (Mascret, Cury 2015), especially in the cases of math-related giftedness (Kao 2015). Also, several authors argue that psychological well-being in general deteriorates throughout middle to late adolescence (Viejo, Gomez-Lopez, Ortega-Ruiz 2018; Shek, Lu-Yin 2018; Archakova, Veraksa, Zotova, Perelygina 2017). However, according to a meta-analysis of the subject, the age-related decline in psychological well-being was found statistically insignificant for gifted children (Jones 2013).

Age, gender and type of giftedness may all influence gifted children's psychological well-being estimate. To address this issue, a sample of gifted children was composed, so as to compare the psychological well-being of teenagers gifted in sports, math and humanities and answer the following questions:

Is there a difference between gifted children's psychological well-being scores depending on their giftedness type (math, humanities and sports)?

Is there a difference between gifted children's psychological well-being scores depending on their gender?

\section{Materials and methods}

The sample comprised 168 teenagers (age 15-17, mean age $16,00 \pm 0,69)$ gifted in math $(n=79)$, humanities $(\mathrm{n}=50)$ and sports $(\mathrm{n}=39), 63$ female and 105 male. The sample was composed with expert recommendations in mind (Melik-Pashaev, Novlyanskiy, Adaskina, Chubuk 2006; Subotnik, Olszewski-Kubilius, Worrell 2011; Salnikov, Hosey, Revenko 2017). Competitive admission into specialized educational programmes for gifted children served as the inclusion criterion. Presidential Physics and Mathematics Lyceum (Saint Petersburg) 
Table 1. Sample description

\begin{tabular}{|c|c|c|c|c|}
\hline \multirow[b]{2}{*}{ Samples } & \multicolumn{2}{|c|}{ Male } & \multicolumn{2}{|c|}{ Female } \\
\hline & $\mathbf{n}$ & $\begin{array}{c}\text { Age, } \\
\text { mean } \pm \text { sd }\end{array}$ & $\mathbf{n}$ & $\begin{array}{c}\text { Age, } \\
\text { mean } \pm \text { sd }\end{array}$ \\
\hline Gifted in math & 62 & $16.2 \pm 0.71$ & 17 & $16.2 \pm 0.81$ \\
\hline Gifted in humanities & 14 & $16.1 \pm 0.36$ & 10 & $16.2 \pm 0.95$ \\
\hline Gifted in sports & 47 & $15.4 \pm 0.49$ & 36 & $15.7 \pm 0.47$ \\
\hline Total & 105 & $16.1 \pm 0.70$ & 63 & $15.9 \pm 0.67$ \\
\hline
\end{tabular}

students admitted into advanced mathematics programmes constituted the math group. The humanities group comprised students from humanities-focused classes of the Centre for Gifted Children (Nizhny Novgorod) admitted into advanced programmes in humanities. The sports group was composed of Olympic Reserve sports schools students from Saint Petersburg admitted into advanced programmes in competitive team sports (synchronized swimming, water polo, football). This division by giftedness type was driven by a suggestion that activity type might influence general psychological well-being and/or its factors independently (Kryukova 1996; Pechko 2014; Khudyakov, Kishchenko 2014; Zudov, Gorfinkel 2016). Sample description is provided in Table 1 .

Psychological well-being was measured with Ryff's Psychological Well-Being Scales (Ryff 1995). There are several adaptations of this questionnaire into Russian (Shevelenkova, Fesenko 2005; Lepeshinsky 2007). In this study, the 54-item version translated and adapted for Russian samples, including teenager samples, by L. V. Zhukovskaya and E. G. Troshikhina (Zhukovskaya, Troshikhina 2011) was used. All 6 factors (purpose in life, autonomy, environmental mastery, personal growth, positive relations with others, and self-acceptance) and the general well-being were examined. Programme and protocol of the study were approved by the ethical committee of Herzen State Pedagogical University by decision no. 5 on 28 January 2019.

Data analysis was performed with the use of RStudio, version 1.1.463. Descriptive statistics were calculated with dplyr package, version 0.8.0.1. Regression analysis with 2 possible predictors (gender and type of giftedness) and their interaction was performed with standard (lm) function for the general well-being score and each separate factor. Due to the unbalanced design and possible interaction between independent variables, type III ANOVA table was used for our models (Fox 2016). Estimated marginal means for contrasts were calculated with emmeans package, version 1.3.4. Normality check for models' residuals was performed with Shapiro-Wilk test, homogeneity of variances was estimated with Bartlett test, autocorrelations were checked with Durbin-Watson statistic. Test results were satisfactory.

\section{Results}

\subsection{Giftedness type and gender}

In our study, both math and sports groups included more boys than girls. In the humanities group, however, girls were prevalent (see Table 2). This difference was statistically significant (Chisquared $=36.341, \mathrm{df}=2$, $\mathrm{p}$-value $=0.00000001285$ ) . Although it might be a sample-specific effect, gender gaps in both math and humanities are typical for the modern Russian society: STEM subjects are widely considered more appropriate for boys, while girls are encouraged to study reading and writingfocused subjects. To account for this effect, interaction between gender and giftedness type was included in regression models.

\subsection{Well-being factors description}

In our study, respondents exhibited the same levels of general well-being as students from a general sample as reported in the adaptation study (Zhukovskaya, Troshikhina 2011). However, they had higher median estimates in autonomy (median difference is 3.0), environmental mastery (median

Table 2. Gender prevalence in gifted groups

\begin{tabular}{|c|c|c|c|c|}
\hline \multirow{2}{*}{ Samples } & \multicolumn{2}{|c|}{$\mathbf{n}$} & \multicolumn{2}{c|}{ \% in type of giftedness } \\
\cline { 2 - 5 } & female & male & female & male \\
\hline Gifted in math & 17 & 62 & 21.52 & 78.48 \\
\hline Gifted in sports & 10 & 29 & 25.64 & 74.36 \\
\hline Gifted in humanities & 36 & 14 & 72.00 & 28.00 \\
\hline
\end{tabular}


Table 3. Descriptive statistics of well-being scales

\begin{tabular}{|l|c|c|c|c|c|c|}
\hline \multicolumn{1}{|c|}{ Samples } & Mean & SD & Median & Mad & Min & Max \\
\hline Autonomy & 32.82 & 5.25 & 33.0 & 5.93 & 19 & 45 \\
\hline Environmental competence & 29.83 & 5.27 & 30.0 & 5.93 & 19 & 45 \\
\hline Personal growth & 35.64 & 4.88 & 36.0 & 5.19 & 20 & 45 \\
\hline Positive relations & 32.61 & 6.07 & 33.0 & 7.41 & 19 & 44 \\
\hline Purpose in life & 32.88 & 6.47 & 33.0 & 7.41 & 15 & 45 \\
\hline Self-acceptance & 32.04 & 6.37 & 32.5 & 6.67 & 11 & 45 \\
\hline General well-being & 195.82 & 24.63 & 194.5 & 25.95 & 138 & 250 \\
\hline
\end{tabular}

difference is 1.0) and personal growth (median difference is 2.0); and lower estimates of positive relations (median difference is -1.0 ), purpose in life (median difference is -1.0) and self-acceptance (median difference is -0.5 ). This might indicate that these well-being factors are deficient in gifted teenagers. Detailed discussion of the procured statistics in comparison with a general sample is a topic for a separate study. Descriptive statistics of well-being factors are reported in Table 3.

\subsection{Well-being factors by gender and giftedness type}

Teenagers of all giftedness types and genders shared similar general well-being scores. However, higher specific factor scores were associated with certain genders and giftedness types (see Table 4). Girls' autonomy score was, on average, 2.89 points lower than boys'; in the humanities group, this gap was even more pronounced at 4.44 points. Gifted boys seem to be more independent of social pressure than girls. Also, girls' environmental mastery score was, on average, 2.22 points lower than boys', with the gap especially wide in the sports group. Being more independent, boys at the same time know well how to use the environment for their benefit. On the other hand, girls' estimates of personal growth were 2.22 points higher than boys', even more so in the sports group. Achieving significant results earlier in their careers, girls in sports have a chance to develop a sense of personal accomplishment and therefore feel personal growth. Girls are also more capable of building intimate empathic relationships than boys (by a mean estimate of 2.36 points), even more so in the math group (see Table 5). Teenagers gifted in math lack goal orientation, compared to both those gifted in humanities (by 3.85 points) and those gifted in sports (by 4.37 points). Self-acceptance score was more or less similar in all groups, but for girls gifted in humanities the estimate was significantly (by 4.29 points) lower than for boys from the samegroup.

Table 4. Contrasts for linear models of well-being factors (general score, autonomy, environmental mastery, personal growth) by gender and giftedness type

\begin{tabular}{|c|c|c|c|c|c|c|c|c|c|c|c|c|c|}
\hline \multirow{2}{*}{ Variable } & \multirow{2}{*}{ Contrast } & \multicolumn{3}{|c|}{ General Well-Being ${ }^{2}$} & \multicolumn{3}{|c|}{ Autonomy ${ }^{3}$} & \multicolumn{3}{|c|}{$\begin{array}{c}\text { Environmental } \\
\text { Mastery }^{4}\end{array}$} & \multicolumn{3}{|c|}{ Personal Growth ${ }^{5}$} \\
\hline & & Est. & SE & $\mathbf{p}$ & Est. & SE & $\mathbf{p}$ & Est. & SE & $\mathbf{p}$ & Est. & SE & $\mathbf{p}$ \\
\hline Gender & $\mathrm{F}-\mathrm{M}^{1}$ & -1.00 & 4.51 & 0.824 & -2.89 & 0.95 & 0.002 & -2.22 & 0.95 & 0.021 & 2.22 & 0.87 & 0.011 \\
\hline \multirow{3}{*}{$\begin{array}{l}\text { Giftedness } \\
\text { Type }\end{array}$} & MA-SP & -7.78 & 5.57 & 0.345 & 1.56 & 1.18 & 0.381 & -1.80 & 1.18 & 0.280 & 0.62 & 1.07 & 0.830 \\
\hline & MA-HU & -10.55 & 5.08 & 0.098 & -0.73 & 1.07 & 0.775 & -0.88 & 1.07 & 0.691 & -1.38 & 0.98 & 0.332 \\
\hline & SP-HU & -2.77 & 5.89 & 0.885 & -2.29 & 1.24 & 0.158 & 0.92 & 1.24 & 0.740 & -2.01 & 1.13 & 0.181 \\
\hline \multirow{3}{*}{$\begin{array}{l}\text { Type: } \\
\text { Gender }\end{array}$} & MA: F-M & 5.49 & 6.67 & 0.411 & -1.35 & 1.41 & 0.340 & -1.61 & 1.41 & 0.255 & 2.33 & 1.28 & 0.070 \\
\hline & SP: F-M & 1.22 & 8.93 & 0.891 & -2.89 & 1.88 & 0.126 & -4.29 & 1.89 & 0.024 & 4.06 & 1.72 & 0.019 \\
\hline & HU: F-M & -9.71 & 7.67 & 0.207 & -4.44 & 1.62 & 0.006 & -0.75 & 1.62 & 0.644 & 0.27 & 1.47 & 0.852 \\
\hline
\end{tabular}

${ }^{1}$ Abbreviations stand for: $\mathrm{F}$ - female, $\mathrm{M}$ - male, MA - gifted in math, SP - gifted in sports, HU - gifted in humanities

${ }^{2}$ Statistics for General Well-Being model: $\mathrm{R}^{2}{ }_{\text {adj }}=0.022, \mathrm{p}=0.124$, F-statistic: 1.758 on 5 and $162 \mathrm{DF}$

${ }^{3}$ Statistics for Autonomy model: $\mathrm{R}_{\text {adj }}^{2}=0.042$, $\mathrm{p}=0.034$, F-statistic: 2.48 on 5 and $162 \mathrm{DF}$

${ }^{4}$ Statistics for Environmental Mastery model: $\mathrm{R}^{2}{ }_{\text {adj }}=0.044, \mathrm{p}=0.031$, F-statistic: 2.532 on 5 and $162 \mathrm{DF}$

${ }^{5}$ Statistics for Personal Growth model: $\mathrm{R}^{2}{ }_{\text {adj }}=0.080, \mathrm{p}=0.002$, F-statistic: 3.886 on 5 and $162 \mathrm{DF}$ 
Table 5. Contrasts for linear models of well-being factors (positive relations, purpose in life, self-acceptance) by gender and giftedness type

\begin{tabular}{|c|c|c|c|c|c|c|c|c|c|c|}
\hline \multirow{2}{*}{ Variable } & \multirow{2}{*}{ Contrast } & \multicolumn{3}{|c|}{ Positive Relations $^{\mathbf{2}}$} & \multicolumn{3}{c|}{ Purpose in Life $^{\mathbf{3}}$} & \multicolumn{3}{c|}{ Self-Acceptance $^{4}$} \\
\cline { 2 - 12 } & & Est. & SE & p & Est. & Est. & SE & p & Est. & Est. \\
\hline Gender & F-M & 2.36 & 1.07 & 0.029 & 0.56 & 2.36 & 1.07 & 0.029 & 0.56 & 2.36 \\
\hline \multirow{3}{*}{$\begin{array}{c}\text { Giftedness } \\
\text { Type }\end{array}$} & MA-SP & -2.59 & 1.33 & 0.128 & -4.37 & -2.59 & 1.33 & 0.128 & -4.37 & -2.59 \\
\cline { 2 - 11 } & MA-HU & -1.10 & 1.21 & 0.632 & -3.85 & -1.10 & 1.21 & 0.632 & -3.85 & -1.10 \\
\cline { 2 - 11 } & SP-HU & 1.48 & 1.40 & 0.541 & 0.51 & 1.48 & 1,40 & 0.541 & 0.51 & 1.48 \\
\hline \multirow{2}{*}{$\begin{array}{c}\text { Type: } \\
\text { Gender }\end{array}$} & MA: F-M & 4.59 & 1.59 & 0.004 & -1.37 & 4.59 & 1.59 & 0.004 & -1.37 & 4.59 \\
\cline { 2 - 11 } & SP: F-M & 1.73 & 2.13 & 0.416 & 4.33 & 1.73 & 2.13 & 0.416 & 4.33 & 1.73 \\
\cline { 2 - 11 } & HU: F-M & 0.76 & 1.83 & 0.677 & -1.27 & 0.76 & 1.83 & 0.677 & -1.27 & 0.76 \\
\hline
\end{tabular}

${ }^{1}$ Abbreviations stand for: $\mathrm{F}$ - female, $\mathrm{M}$ - male, MA - gifted in math, SP - gifted in sports, HU - gifted in humanities

${ }^{2}$ Statistics for Positive Relations model: $\mathrm{R}^{2}{ }_{\text {adj }}=0.086, \mathrm{p}=0.001$, F-statistic: 4.151 on 5 and $162 \mathrm{DF}$

${ }^{3}$ Statistics for Purpose in Life model: $\mathrm{R}^{2}{ }_{\text {adj }}=0.054, \mathrm{p}=0.015$, F-statistic: 2.922 on 5 and $162 \mathrm{DF}$

${ }^{4}$ Statistics for Self-Acceptance model: $\mathrm{R}^{2}{ }_{\text {adj }}=0.056, \mathrm{p}=0.013$, F-statistic: 2.983 on 5 and $162 \mathrm{DF}$

\section{Discussion}

Our results revealed that teenagers gifted in math, humanities and sports exhibit no significant differences between their general well-being scores, either as a merged sample or when divided by gender. At the same time, discrepancies in specific wellbeing factor scores were identified. This result has been obtained in previous studies, e. g. by Maureen Neihart, Timothy Jones (Neihart 1999; Jones 2013).

According to regression models, specific wellbeing factors correlate with gender and giftedness type. This is partially explained by the gender gap present in the respondents' groups; in the math group, boys are prevalent, while in the humanities group there are more girls. Pairwise comparison of means suggests that gender impacts most of the well-being factors, while giftedness type plays a lesser role.

Gender influence was evident in the autonomy score, which was higher in boys than in girls. Boys are more likely to stand their ground against social pressure and more independent; they feel in control of their behaviour and evaluate themselves on the basis of personal standards. Girls are more susceptible to social pressure and other people's expectations and consider other people's opinions when making decisions. Boys also exhibit higher levels of environmental mastery than girls. Girls, on the other hand, showed higher personal growth estimates. In both cases, the differences were the most pronounced in the sports group. The same trend was also revealed for the purpose in life factor, where girls gifted in sports had higher scores than boys.

Considering the common profile of correlations between well-being factor scores and gender, this may be explained by the process of assimilation of gender norms unfolding in adolescence. However, the fact that the extent of the differences depended on the activity type must also be noted.

In the humanities group, the autonomy estimate gap between boys and girls was especially evident. Adolescents gifted in humanities are typically characterized by deeper reflection about life and sensitivity to social relations (Pechko 2014). Higher potential in humanities reinforces the age-specific process. The same reinforcement of the age-related trend is found among those gifted in math. Girls from this sample outmatch boys in the ability to build more satisfying relationships characterized by close and emotionally deep connections with other people. Adolescents gifted in math typically struggle with developing close interpersonal relationships (Kryukova 1996), unlike other groups of gifted teenagers.

Giftedness type was found relevant for the purpose in life factor. Teenagers gifted in humanities and in sports tend to have a strong sense of meaning and goal orientation, while adolescents gifted in math usually experience a lack of direction and the feeling of meaninglessness. In the sports group, girls had much higher estimates of goal orientation than boys. Here, the teenagers' perspectives might be influenced by their achievements. For physiological reasons, girls achieve high results in sports earlier than boys. By late adolescence they clearly understand their potential and have a plan for the utilisation of their talents. This fact may also explain the score gap in personal growth and environmental mastery identified in the sports group, as girls are faced with harder challenges than boys in late adolescence. As for the humanities group, the gender difference in personal growth and environmental mastery scores may be a result of the challenging educational 
programme aimed at admission into the very restricted number of top university-level programmes. For those gifted in math, the future stays partially vague because of the wide range of opportunities available; these teenagers can count on being in high demand while making use of their advanced analytical skills.

As for the self-acceptance score, no direct influence of gender and giftedness type was observed, but the interaction was significant. Higher estimates of self-acceptance were found in groups of teenagers whose talents are considered unconventional for their gender (math for girls and humanities for boys). This might be explained by the importance of self-acceptance in relations with the opposite sex, which might reduce potential negative effects of involvement in "gender-atypical" activities.

To answer the first question posed, there are no differences between the general well-being scores of adolescents gifted in math, humanities and sports. Specific factors of psychological well-being, such as purpose in life and self-acceptance, are influenced by the giftedness type. To answer the second question, gender differences may be explained by the agespecific trends of personal development in adolescence and are not specifically linked to the giftedness type. Giftedness type might, however, reinforce these trends, making them more evident.

Our study has certain limitations, with the first one linked to the criteria for the selection of gifted adolescents. For this study, competitive admission into advanced educational programmes served as the criterion. Such admission relies on the selection procedure and judges' expertise. Also, not all admitted children are equally successful. Some respondents already have well-acknowledged achievements, such as medals from international competitions; others struggle with following the programme. The second limitation of our study is that all respondents are educated in specialised educational institutions, spending their time in unusual environments among peers of similar backgrounds. Considering the big fish little pond effect described by Herbert Marsh and Joseph Parker, the perception of self and personal achievements is based on comparison with peers (Marsh, Parker 1984), so a gifted teenager feels that he/she achieved more in his/her life compared to children who fall within the normal range of ability but not to his/her gifted peers. Thus, the results obtained in this study cannot be projected onto samples of gifted teenagers educated in standard secondary schools without further empirical proof. The sample imbalance stemming from the specific features of the educational institutions and the limited number of advanced programme attendees only provides basis for rough estimates of gender specifics and age dynamics of well-being in gifted adolescents. Our data demonstrates the importance of examining giftedness type- and gender-related data as part of the studies of gifted teenagers' well-being.

\section{Conclusions}

Psychological well-being is essential for personal and professional fulfilment of gifted adolescents, and studies of psychological well-being are highly demanded both by researchers and educators. The results of reported studies on well-being and giftedness are inconsistent, with discussions spanning several decades. Theoretical analysis suggests that gifted adolescents' psychological well-being might depend on their type of giftedness, gender, and age. Data obtained in this study suggest that gender and giftedness type play an important role in specific well-being factors, while not in the general wellbeing score. Therefore, gender, age and giftedness type should be taken into account when studying gifted adolescents' psychological well-being.

\section{References}

Archakova, T. O., Veraksa, A. N., Zotova, O. Yu., Perelygina, E. B. (2017) Sub'ektivnoe blagopoluchie u detej: instrumenty izmereniya i vozrastnaya dinamika [Subjective well-being in children: Measurement tools and age dynamics]. Psikhologicheskaya nauka i obrazovanie - Psychological Science and Education, vol. 22, no. 6, pp. 68-76. DOI: 10.17759/pse.2017220606 (In Russian)

Bergold, S., Wirthwein, L., Rost, D. H., Steinmayr, R. (2015) Are gifted adolescents more satisfied with their lives than their non-gifted peers? Frontiers in Psychology, vol. 6, article 1623. DOI: 10.3389/fpsyg.2015.01623 (In English)

Boazman, J., Sayler, M. (2011) Personal well-being of gifted students following participation in an early collegeentrance program. Roeper Review, vol. 33, no. 2, pp. 76-85. DOI: 10.1080/02783193.2011.554153 (In English)

Chen, X. J., Fan, X. T., Cheung, H. Y., Wu, J. (2018) The subjective well-being of academically gifted students in the Chinese cultural context. School Psychology International, vol. 39, no. 3, pp. 291-311. DOI: 10.1177/0143034318773788 (In English)

Fouladchanga, M., Kohgard, A., Salah, V. (2010) A study of psychological health among students of gifted and nongifted high schools. Procedia Social and Behavioral Sciences, vol. 5, pp. 1220-1225. DOI: 10.1016/j.sbspro.2010.07.264 (In English) 
Fox, J. (2016) Applied regression analysis and generalized linear models. $3^{\text {rd }}$ ed. Thousand Oaks: Sage Publications, 665 p. (In English)

Harder, B., Vialle, W., Zieglera, A. (2014) Conceptions of giftedness and expertise put to the empirical test. High Ability Studies, vol. 25, no. 2, pp. 83-120. DOI: 10.1080/13598139.2014.968462 (In English)

Jin, S.-U., Moon, S. M. (2006) A study of well-being and school satisfaction among academically talented students attending a science high school in Korea. Gifted Child Quarterly, vol. 50, no. 2, pp. 169-184. DOI: 10.1177/001698620605000207 (In English)

Jones, T. (2013) Equally cursed and blessed: Do gifted and talented children experience poorer mental health and psychological well-being? Educational and Child Psychology, vol. 30, no. 2, pp. 44-66. (In English)

Kao, Ch. (2015) Mathematically gifted adolescent females' mixed sentiment toward gender stereotypes. Social Psychology of Education, vol. 18, pp. 17-35. DOI: 10.1007/s11218-014-9278-2 (In English)

Khudyakov, V. P., Kishchenko, S. E. (2014) Psikhologicheskaya podgotovka sportsmenov v komandnykh vidakh sporta $\mathrm{k}$ trenirovochnomu protsessu i sorevnovaniyu [Psychological preparation of athletes in team sports for the training process and competition]. Innovatsionnye proekty i programmy v obrazovanii - Innovative Projects and Programs in Education, no. 2, pp. 57-62. (In Russian)

Kroesbergen, E. H., van Hooijdonk, M., van Viersen, S. et al. (2016) The psychological well-being of early identified gifted children. Gifted Child Quarterly, vol. 60, pp. 16-30. (In English)

Kryukova, E. A. (1996) Individual'nye osobennosti matematicheskoj odarennosti shkol'nikov i problemy ikh psikhologicheskoj podderzhki (iz opyta raboty psikhologa fiziko-matematicheskoj shkoly) [Specific features of mathematical endowments of school students and a problem of their psychological support (from experience of the psychologist of physical and mathematical school)]. In: Obrazovanie detej $i$ molodezhi: sovremennye podkhody [Education of children and youth: Modern approaches]. Moscow: University of the Russian Academy of Education Publ., pp. 31-47. (In Russian)

Lepeshinsky, N. N. (2007) Adaptatsiya oprosnika "Shkaly psikhologicheskogo blagopoluchiya" K. Riff [Adaptation of the questionnaire "Scale of psychological wellbeing" K. Riff]. Psikhologicheskii zhurnal, no. 3, pp. 24-37. (In Russian)

Marsh, H. W., Parker, J. W. (1984) Determinants of student self-concept: Is it better to be a relatively large fish in a small pond even if you don't learn to swim as well? Journal of Personality and Social Psychology, vol. 47, no. 1, pp. 213-231. DOI: 10.1037/0022-3514.47.1.213 (In English)

Martin, L. T., Burns, R. M., Schonlau, M. (2010) Mental disorders among gifted and nongifted youth: A selected review of the epidemiologic literature. Gifted Child Quarterly, vol.54, no. 1, pp. 31-41.DOI: 10.1177/0016986209352684 (In English)

Mascret, N., Cury, F. (2015) “I'm not scientifically gifted, I'm a girl”: Implicit measures of gender-science stereotypes - preliminary evidence. Educational Studies, vol. 41, no. 4, pp. 462-465. DOI: 10.1080/03055698.2015.1043979 (In English)

Melik-Pashaev, A. A., Novlyanskaya, Z. N., Adaskina, A. A., Chubuk, N. F. (2006) Khudozhestvennaya odarennost' detej, ee vyyavlenie i razvitie [Artistic talent of children, its identification and development]. Dubna: Phoenix+ Publ., 112 p. (In Russian)

Nail, J. M., Evans, J. G. (1997) The emotional adjustment of gifted adolescents: A view of global functioning. Roeper Review, vol. 20, no. 1, pp. 18-21. DOI: 10.1080/02783199709553845 (In English)

Neihart, M. (1999) The impact of giftedness on psychological well-being: What does the empirical literature say? Roeper Review, vol. 22, no. 1, pp. 10-17. DOI: 10.1080/02783199909553991 (In English)

Pechko, L. P. (2014) Kul'turno-esteticheskie otnosheniya v razvitii gumanitarnoj odarennosti [Cultural and aesthetic relations in the development of humanitarian giftedness]. In: I. Yu. Gorskaya, M. R. Shamtieva (eds.). Khudozhestvennoe obrazovanie: problemy i perspektivy razvitiya. Materialy mezhdunarodnoj zaochnoj nauchnoprakticheskoj konferentsii Instituta muzykal'nogo $i$ khudozhestvennogo obrazovaniya UrGPU [Proceeding of the international correspondence scientific-practical conference of the Institute of music and art education of USPU "Art education: problems and prospects of development"]. Ekaterinburg: Ural State Pedagogical University Publ., pp. 102-108. (In Russian)

Peterson, J. S. (1997) Bright, tough, and resilient — and not in a gifted program. Journal of Secondary Gifted Education, vol. 8, no. 3, pp. 121-136. DOI: 10.1177/1932202X9700800304 (In English)

Rodenko, E. A. (2010) Izuchenie urovnya psikhologicheskogo blagopoluchiya lichnosti podrostkov [Study of the level of psychological well-being of adolescents]. In: O. Yu. Shchelkova (ed.). Materialy Mezhdunarodnoj nauchno-prakticheskoj konferentsii molodykh uchenykh "Psikhologiya XXI veka" [Proceedings of the International scientific and practical conference of young scientists "Psychology of the XXI century"]. Saint Petersburg: Saint Petersburg State University Publ., pp. 225-227. (In Russian)

Ryan, R. M., Deci, E. L. (2001) On happiness and human potentials: A review of research on hedonic and eudaimonic well-being. Annual Review of Psychology, vol. 52, pp. 141-166. DOI: 10.1146/annurev.psych.52.1.141 (In English)

Ryan, R. M., Huta, V., Deci, E. L. (2008) Living well: A self-determination theory perspective on eudaimonia. Journal of Happiness Studies, vol. 9, no. 1, pp. 139-170. DOI: 10.1007/s10902-006-9023-4 (In English) 
Ryff, C. D. (1989) Happiness is everything, or is it? Explorations on the meaning of psychological well-being. Journal of Personality and Social Psychology, vol. 57, no. 6, pp. 1069-1081. DOI: 10.1037//0022-3514.57.6.1069 (In English)

Ryff, C. D. (1995) The structure of psychological well-being revisited. Journal of Personality and Social Psychology, vol. 69, no. 4, pp. 719-727. DOI: 10.1037/0022-3514.69.4.719 (In English)

Ryff, C. D. (2014) Psychological well-being revisited: Advances in the science and practice of eudaimonia. Psychotherapy and Psychosomatics, vol. 83, no. 1, pp. 10-28. DOI: 10.1159/000353263 (In English)

Salnikov, V. A., Hosey, S. P., Revenko, E. M. (2017) Odarennost' v sisteme sportivnogo otbora: problemy i perspektivy [Aptitude in the system of sports selection: Problems and prospect]. Uchenye zapiski universiteta imeni P. F. Lesgafta, no. 4 (146), pp. 194-201. (In Russian)

Shek, D. T., Lu-Yin, L. (2018) Psychosocial factors influencing individual well-being in Chinese adolescents in Hong Kong: A six-year longitudinal study. Applied Research Quality Life, vol. 13, no. 10, pp. 561-584. DOI: 10.1007/ s11482-017-9545-4 (In English)

Shevelenkova, T. D., Fesenko, P. P. (2005) Psikhologicheskoe blagopoluchie lichnosti [Psychological well-being of the individual]. Psikhologicheskaya diagnostika, no. 3, pp. 95-121. (In Russian)

Subotnik, R. F., Olszewski-Kubilius, P., Worrell, F. C. (2011) Rethinking giftedness and gifted education: A proposed direction forward based on psychological science. Psychological Science in the Public Interest, vol. 12, no. 1, pp. 3-54. DOI: 10.1177/1529100611418056 (In English)

Tatli, C. (2017) Investigating of the subjective well-being of gifted adolescents. New Trends and Issues Proceedings on Humanities and Social Sciences, vol. 4, no. 4, pp. 56-63. DOI: 10.18844/prosoc.v4i4.2595 (In English)

Vedikova, E. Yu., Kalyagina, E. A. (2018) Osobennosti psikhologicheskogo blagopoluchiya starshikh podrostkov s priznakami odarennosti [Peculiarities of psychological well-being of seniors with signs of giftedness]. In: A. A. Sukiasyan (ed.). Problema protsessa samorazvitiya i samoorganizatsii v psikhologii i pedagogike. Sbornik statej po itogam Mezhdunarodnoj nauchno-prakticheskoj konferentsii [The problem of the process of selfdevelopment and self-organization in psychology and pedagogy. Proceedings of the International scientific and practical conference]. Sterlitamak: International Research Agency Publ., pp. 57-59. (In Russian)

Viejo, C., Gomez-Lopez, M., Ortega-Ruiz, R. (2018) Adolescents' psychological well-being: A multidimensional measure. International Journal of Environmental Research and Public Health, vol. 15, no. 10, article 2325. DOI: 10.3390/ijerph15102325 (In English)

Zeidner, M., Shani-Zinovich, I. (2011) Do academically gifted and nongifted students differ on the Big-Five and adaptive status? Some recent data and conclusions. Personality and Individual Differences, vol. 51, no. 5, pp. 566-570. DOI: 10.1016/j.paid.2011.05.007 (In English)

Zhukovskaya, L. V., Troshikhina, E. G. (2011) Shkala psikhologicheskogo blagopoluchiya K. Riff [K. Ryff's Scale of psychological well-being]. Psikhologicheskii zhurnal, vol. 32, no. 2, pp. 82-93. (In Russian)

Zudov, S. I., Gorfinkel, V. A. (2016) Osobennosti volevykh kachestv podrostkov, zanimayushchikhsya sportom [Features volitional qualities of adolescents involved in sports]. In: E. M. Dorozhkin, V. A. Fedorov (eds.). Innovatsii v professional'nom i professional'no-pedagogicheskom obrazovanii. Materialy 21-oj Mezhdunarodnoj nauchno-prakticheskoj konferentsii [Proceedings of the $21^{\text {st }}$ International scientific and practical conference "Innovations in professional and vocational teacher education"]. Ekaterinburg: Russian State Vocational Pedagogical University Publ., pp. 267-270. (In Russian) 